\title{
The historical development of pharmacopoeias and the inclusion of exotic herbal drugs with a focus on Europe and Brazil
}

\author{
Domingos Tabajara de Oliveira Martins ${ }^{\mathrm{a}}$, Eliana Rodrigues ${ }^{\mathrm{b}}$, Laura Casu ${ }^{\mathrm{c}}$, Guillermo Benítez ${ }^{\mathrm{d}}$, \\ Marco Leonti ${ }^{\mathrm{e}, *}$ \\ ${ }^{a}$ Department of Basic Sciences in Health, Faculty of Medicine, Federal University of Mato Grosso (UFMT), 78060-900, Cuiabá, MT, Brazil \\ ${ }^{\mathrm{b}}$ Center for Ethnobotanical and Ethnopharmacological Studies, Department of Environmental Sciences, UNIFESP, Brazil \\ ${ }^{c}$ Department of Life and Environmental Sciences, University of Cagliari, Via Ospedale 72, 09124, Cagliari, Italy \\ ${ }^{\mathrm{d}}$ Department of Botany, University of Granada, Campus Universitario de Cartuja s/n, 18071, Granada, Spain \\ ${ }^{\mathrm{e}}$ Department of Biomedical Sciences, University of Cagliari, Via Ospedale 72, 09124, Cagliari, Italy
}

A R T I C L E I N F O

\section{Keywords:}

Exotic Materia medica

Globalization

Brazil

Europe

Pharmacopoeia

Pharmacognosy

\begin{abstract}
A B S T R A C T
Ethnopharmacological relevance: In spite of the rich bio-cultural diversity found in the Neotropics relatively few herbal drugs native to South America are included in the global pharmacopoeia.

Material and methods: In the attempt to historically explain the inclusion of herbal drugs into official pharmacopoeias we consider the disparate epidemiology and cultural evolution of the New and the Old World. We then trace the development of pharmacopoeias and review forces that worked towards and against the synchronization of pharmacopoeias and highlight the role of early chemical and pharmacological studies in Europe. Finally, we compare the share of exotic and native herbal drug species included in the Brazilian Pharmacopoeia with the share of exotic and native species included in the European Pharmacopoeia as well as those used for products registered with ANVISA.

Results: The domination of Eurasian herbal drugs in the European Pharmacopoeia seems to be conditioned by the geographical extension of Eurasia, which facilitated the interchange of materia medica and the creation of a consensus of use since ancient times. At the time of the Conquest the epidemiology of the Amerindian populations resembled that of pre-agriculturalist societies while no written consensus around efficacious medicine existed. Subsequently, introduced and well-tried plant species of the Old World gained therapeutic importance in the New World.

Conclusion: The research focus in Europe and the US resulted in a persistence of herbal drugs with a historic importance in the European and US pharmacopoeias, which gained a status as safe and efficacious. During the last decades only few ethnopharmacological field-studies have been conducted with indigenous Amerindian groups living in the Brazilian Amazon, which might be attributable to difficulties in obtaining research permissions. Newly adopted regulations regarding access to biodiversity and traditional knowledge as well as the simplified procedure for licencing herbal medicinal products in Brazil prospects an interesting future for those aiming at developing herbal medicine based on bio-cultural diversity and respecting the protocols regulating benefit sharing.
\end{abstract}

\section{Introduction}

\subsection{Biodiversity and cultural diversity of Brazil}

The American continent harbours around 125,000 native vascular plant species (Ulloa et al., 2017; Tropicos: http://www.tropicos.org/ Project/VPA) or $33 \%$ of the known 383,000 vascular plants species worldwide (Ulloa et al., 2017). Particularly rich are the Neotropics with an estimated 90,000 to 110,000 plant species (Antonelli and Sanmartín, 2011), half of which occur in the Amazon basin (Hubbell et al., 2008). With up to 50,000 species, Brazil has the largest flora in the Neotropics (Lewinsohn and Prado, 2005; Shepherd, 2003; Ulloa et al., 2017). Besides a rich biodiversity around 300 Amerindian groups (including ca. 900,000 individuals) associated with 274 different languages are living in Brazil (IBGE, 2019; survivalinternational.org). Around 325,000 live now in urban and 570,000 in rural areas (ISA, 2019; IBGE, 2019).

\footnotetext{
* Corresponding author.

E-mail addresses: marcoleonti@netscape.net, mleonti@unica.it (M. Leonti).
} 
Moreover, around 2700 culturally distinct Quilombola communities, formed by descendants of Afro-Brazilian runaway slaves, exist throughout the country (FCP, 2019). Several communities living mostly in rural areas are derived from the miscegenation of European, Amerindian, and Afro-Brazilian descendants including Caboclo river dwellers, coastal Caiçara fishermen, Seringueiro rubber tappers and Jangadeiro raftsmen (Ribeiro, 2018).

\subsection{Herbal drugs from the neotropics included in the European Pharmacopoeia}

Although the different indigenous groups of Brazil and the Americas in general have a long standing tradition regarding the practice and understanding of herbal medicine and materia medica (e.g., Rodrigues, 2006; Odonne et al., 2013; Monigatti et al., 2013; van Andel et al., 2014; Bieski et al., 2015; Paniagua-Zambrana et al., 2015; Geck et al., 2016; Pedrollo et al., 2016, Ribeiro et al., 2017) relatively few medicinal plants native to the Americas and specifically Brazil have been developed into globally important herbal medicines (Brandão et al., 2008; Heinrich et al., 2014; Dutra et al., 2016). Currently, the European Pharmacopoeia (Ph. Eur. 9.5, 2017) includes 30 monographs treating 18 herbal drug aggregates native to Meso and South America ${ }^{1}$ (see Fig. 1, Table 1 and Supplementary Table A).

Several herbal drugs from the Neotropics were of historical importance in Europe and the USA but later excluded from pharmacopoeias and dispensatories. For example, the core wood of Guaiacum officinale L. (lignum vitae) was imported to Europe from the West Indies (Caribbean archipelago) as a cure for syphilis, but later found to be ineffective and thus abandoned (Waugh, 1982; Mann, 1984). Other sudorific drugs such as the root of Sarsaparilla (Smilax spp.) from Mesoamerica (Felter and Lloyd, 1898) and lignum sassafras (Sassafras albidum (Nutt.) Nees) from North America were used as substituents for the ineffective $G$. officinale until it was realized that also these drugs were not effective (Munger, 1949). Jalap root (also named 'root of Michoacán', mostly Ipomoea purga (Wender) Hayne but also including roots of other Ipomoea spp., see Pereda-Miranda et al. (2006) and Linares and Bye (1987)) is described in the 'Codex de la Cruz Badiano' (Gates, 2000) as well as in the 'Historia Natural de Nueva España' (Hernández, 1959: II, 456). This was imported to Europe as a substitute for Mediterranean purgatives such as scammony (Convolvulus scammonia L.) as early as 1610 (Castañeda-Gómez and Pereda-Miranda, 2011). Jalap root was included in the commentary to the American pharmacopoeia, the Dispensatory of the United States (Wood and Bache, 1833) and still appeared in the 25th edition of the Dispensatory of the United States of America (Osol and Farrar, 1955) but later excluded. Also in Europe, jalap root was included in several important pharmacy books (e.g. Stocker, 1810; Bigelow, 1822; Felter and Lloyd, 1898) and was part of the Edinburgh New Dispensatory (Duncan, 1803) as well as the London Dispensatory (Thomson, 1826). Jalap was also present in the German Pharmacopoeia from 1872 and 1926 among descriptions for preparations of drugs such as Tinctura Resinae Jalape, Tubera Jalapae, Resina Jalapae, Pilulae Jalapae and Sapo jalapinus, but excluded in the following versions (Eich, 2008). The reason for excluding jalap root from the officinal materia medica was that even

\footnotetext{
${ }^{1}$ 1. Arachis hypogaea L., 2. Myroxylon balsamum (L.) Harms var. perierae (Royle) Harms, 3. Myroxylon balsamum (L.) Harms var. balsamum, 4. Peumus boldus Molina, 5. Capsicum annuum L. and Capsicum frutescens L., 6. Cinchona pubescens Vahl (Cinchona succirubra Pav.), Cinchona calisaya Wedd., (Cinchona ledgeriana Moens ex Trimen), 7. Gossypium hirsutum L. and Gossypium spp., 8. Paullinia cupana Kunth, 9. Helianthus annuus L., 10. Carapichea ipecacuanha (Brot.) L. Andersson (Cephaelis ipecacuanha (Brot.) A. Rich., Cephaelis acuminata H.Karst.), 11. Ilex paraguariensis A.St.-Hil., 12. Passiflora edulis Sims, 13. Quillaja saponaria Molina, 14. Krameria lappacea (Dombey) Burdet \& B.B. Simpson, 15. Datura stramonium L., 16. Aloysia citrodora Paláu, and the pantropical: 17. Cocos nucifera L. and 18. Eclipta prostrata (L.) L.
}

minimal overdosing may cause sever inflammations of the mucous membranes of the intestine and colon due to the resin glycosides, which are able to dissolve lecithin from the epithelial intestinal cells (Eich, 2008). Another remarkable example is Quassia amara L., popularly known as 'Quinquina de Cayenne', which was widely used as a febrifuge and antimalarial drug in Europe, and included in some European pharmacopoeias such as the Pharmacopoeia of the Royal College of Physicians of London (Healde and Latham, 1793) and the Farmacopea Oficial Española, (6th edition from 1884) as well as in several important medical books (e.g., Gray, 1821; Christison, 1842; Felter and Lloyd, 1898; Cullen, 1789). The extract and derivatives of $Q$. amara leaves have been proven active against malaria in vivo (Ajaiyeoba et al., 1999; Bertani et al., 2006) and the potent antimalarial and anticancer simalikalactone $\mathrm{E}$ has been patented, but accusations of biopiracy are hampering any further development into a pharmaceutical drug (see Bourdy et al. (2017) for a thorough discussion). Q. amara wood is mentioned in the British Herbal Pharmacopoeia from 1996, the British Herbal Compendium from 1992, the 32nd edition of Martindale (The Complete Drug Reference) and the second edition of the Physicians' Desk Reference for Herbal Medicine but it is not included in the Ph. Eur. 9.5 (2017). Cascarilla stem bark, predominantly deriving from Croton eluteria (L.) W. Wright or Croton cascarilla (L.) L. (Evans et al., 2009) was much appreciated for its bitter and aromatic quality and used as a tonic stimulant, for treating fever, vomiting, dysentery and menorrhagia (Gray, 1821). It was often combined with Cinchona sp. bark and generally prepared as an infusion (Thomson, 1862) but currently not included in the Ph. Eur. or the U.S. Pharmacopoeia (USP). Extracts of coca (Erythroxylon spp.) were included in the Farmacopea Oficial Española (Anonymous, 1884) as 'Vino de coca del Perú' and in Felter and Lloyd (1898) as 'Vinum Erythroxili' but today coca leaves are banned from being imported and sold in Europe and the US under the 'Single Convention on Narcotic Drugs' from 1961. Thus, pharmacopoeias and dispensatories are not static while the inclusion and persistence of (herbal) drugs in pharmaceutical compendia is related to their effectiveness and safety as well as dependent on political considerations.

\section{Research question}

In the attempt to explain the inclusion and exclusion of herbal drugs into pharmacopoeias we pursue the question as to why only few herbal drugs native to Meso- and South America, and specifically Brazil, are included in the Ph. Eur. 9.5 (2017) as well as in the current edition of the Brazilian Pharmacopoeia (2010), notwithstanding the rich biocultural diversity of the Neotropics.

\section{Methodology}

\subsection{Organization of the text}

The article assumes a historical perspective using the different epidemiology and cultural evolution of the New (Americas) and the Old World (Eurasia and Africa) as a backdrop against which the development of herbal medicine and pharmacopoeias is projected. In section 4 we consider the epidemiological situation of pre-Columbian America and the relatively short interaction with Old World crowd diseases in the differential development of herbal medicine with respect to the Old World. With the help of existing literature we discuss the origin and purpose of pharmacopoeias and sketch the development of pharmacopoeias in Europe and the Western world (section 5) pointing out how newly discovered and occupied territories during the period of colonization and the search for efficacious medicines led to the inclusion of exotic herbal drugs and remedies. In sequence, the racial, economic and social forces working towards and against the process of homogenization of herbal pharmacopoeias are reviewed. In section 6 always based on the analysis of existing literature, we explain how early efforts in 


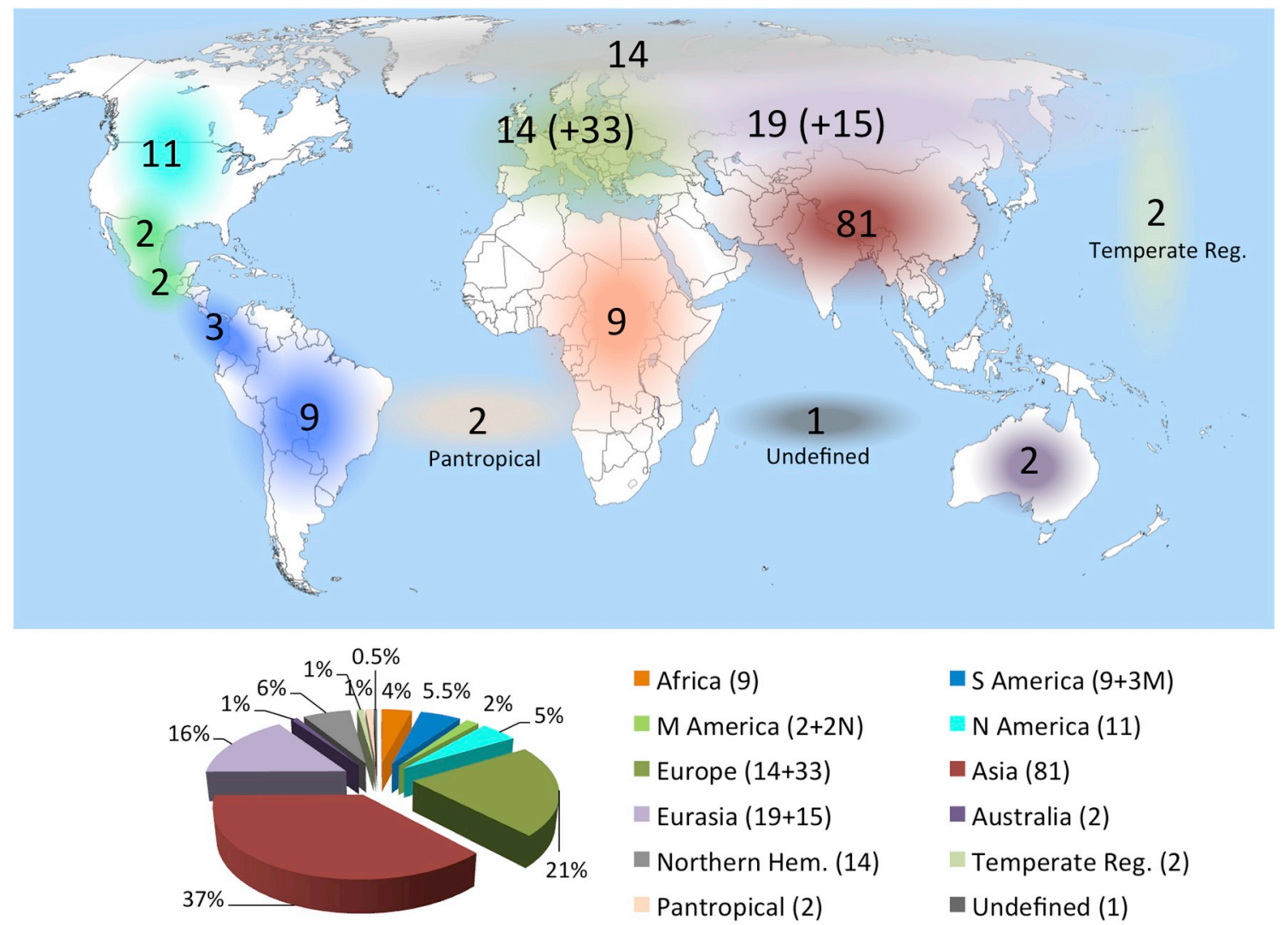

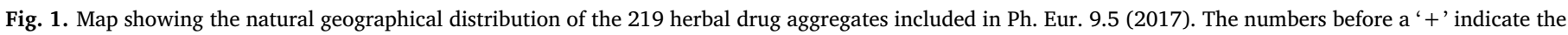

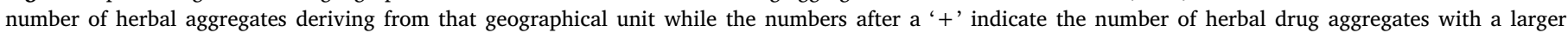

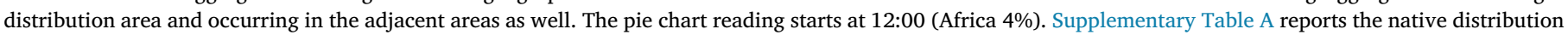
for each herbal drug aggregate.

Table 1

The 219 herbal drug aggregates included in the Ph. Eur. 9.5 (2017) arranged by their native distribution.

\begin{tabular}{|c|c|c|c|c|c|}
\hline & Origin & $\mathrm{n}$ & & Origin & $\mathrm{n}$ \\
\hline A & Africa & 9 & $\mathbf{N}$ & Eurasia + Greenland & 1 \\
\hline B & America (M) & 2 & $\mathbf{0}$ & Europe & 14 \\
\hline C & America $(\mathrm{M}, \mathrm{N})$ & 2 & $\mathbf{P}$ & Europe + Africa $(\mathrm{N})$ & 9 \\
\hline $\mathbf{D}$ & America $(\mathrm{M}, \mathrm{S})$ & 3 & $\mathbf{Q}$ & Europe + Africa $(\mathrm{N})+$ Asia $(\mathrm{CW})$ & 2 \\
\hline $\mathbf{E}$ & America $(\mathrm{N})$ & 11 & $\mathbf{R}$ & Europe + Africa $(\mathrm{N})+$ Asia $(\mathrm{SW})$ & 14 \\
\hline $\mathbf{F}$ & America (S) & 9 & $\mathbf{S}$ & Europe + Africa $(\mathrm{N})+$ Asia $(\mathrm{W})$ & 3 \\
\hline G & Asia & 70 & $\mathbf{T}$ & Europe + America $(\mathrm{N})$ & 1 \\
\hline $\mathbf{H}$ & Asia (SE) & 6 & $\mathbf{U}$ & Europe + Asia (SW) & 2 \\
\hline I & Asia (SW) & 2 & $\mathbf{V}$ & Europe + Asia $(W)$ & 2 \\
\hline $\mathbf{J}$ & Asia (W) & 3 & W & Northern Hemisphere & 14 \\
\hline $\mathbf{K}$ & Australia & 2 & $\mathbf{X}$ & Temperate regions & 2 \\
\hline $\mathbf{L}$ & Eurasia & 19 & $\mathbf{Y}$ & Tropics & 2 \\
\hline \multirow[t]{2}{*}{ M } & Eurasia + Africa $(\mathrm{N})$ & 14 & $\mathbf{Z}$ & Undefined & 1 \\
\hline & & & & TOTAL & 219 \\
\hline
\end{tabular}

CW: Central and West; M: Meso; N: North; S: South; SE: Southeast; SW: Southwest; W: Western.

pharmacognosy and chemistry in Europe led to a preferential investigation and characterization of herbal medicines and chemicals included in the official European pharmacopoeias and generally of those herbal drugs widely used in Europe and thus commercially important, whether exotic or native.

In section 7 we finally sketch the development of the Brazilian Pharmacopoeia and compare the herbal drugs included in the latest version with those herbal drugs licenced by the 'Agência Nacional de Vigilância Sanitária do Brasil' (ANVISA database 2016, see Carvalho et al., 2018) and those included in a popular book entitled 'Plantas
Medicinais no Brasil: Nativas e Exóticas' (Lorenzi and Matos, 2008). We showcase how exotic species dominate the officinal and licenced products and highlight the untapped potential of traditional herbal medicine and biodiversity of Brazil.

\subsection{Selection of references for comparison}

'Plantas Medicinais no Brasil: Nativas e Exóticas' reflects a consensus about the most important medicinal plants used in traditional and folk herbal medicine across Brazil (Lorenzi and Matos, 2008 p. 5) and has not the pretention to be complete. It was chosen as a reference for this comparison because it is one of the few and better books on this subject for Brazil suiting the purpose. Alternatively the 6 vols. by Manuel Pio Correia entitled 'Dicionário das Plantas Úteis do Brasil e das Exóticas Cultivadas', published from 1926 onwards and containing approximately 10,000 species could have been used. However, Pio Correia (1926) does not follow a consensus approach of ethnobotanical uses and the taxonomy is outdated. .

\subsection{Handling of monographs, herbal drug species and their geographic distribution}

Herbal drug monographs in the European Pharmacopoeia 9.5 (2017) treating the same herbal drug species (e.g. Thymi herba and Thymi typo thymolo aetheroleum) were aggregated and counted as one, as well as alternative herbal drug species of the same genus included in one monograph (e.g. Salix purpurea L., S. daphnoides Vill., S. fragilis L.) and termed "herbal drug aggregates". The two monographs on Balsamum peruvianum (Myroxylon balsamum (L.) Harms var. perierae (Royle) Harms) and Balsamum tolutanum (Myroxylon balsamum (L.) 
Harms var. balsamum) were treated separately. Homeopathics and starch sources were not considered but Cetraria islandica (L.) Ach. was included. For the 5th Brazilian Pharmacopoeia (ANVISA, 2010) we considered the 56 herbal drug monographs as 55 herbal drug aggregates including 54 plant species and two subspecies of Myroxylum balsamum (without considering taxa used for the production of sugar and starch).

Latin names appearing in the Ph. Eur. 9.5 (2017) as well as the Brazilian Pharmacopoeia (ANVISA, 2010) have been adapted according to www.theplantlist.org while for the geographical distribution of the herbal taxa the broad natural distribution patterns according to several modern floras, such as the Flora of North America (http://www.efloras. org/flora_page.aspx?flora_id=1), the Flora of China (http://www. efloras.org/flora_page.aspx?flora_id=2), the Flora do Brasil 2020 (http://floradobrasil.jbrj.gov.br/) and the Flora Iberica (Castroviejo et al., 1986-2012) were followed. As the geographical origin, especially that of cultivated taxa, is often not exactly known, we define 'native distribution' as the geographical distribution for which human activity is apparently not responsible. For cultivated plants we have followed the native distributions mentioned in Zohary and Hopf (2000).

\section{Epidemiology in the Old World and the New World and consensus about herbal medicines}

Agriculture and animal husbandry evolved independently in various regions of the world but started first in the fertile-crescent in Mesopotamia (Zohary and Hopf, 2000; Diamond, 2002). The Neolithic Demographic Transition together with animal husbandry in the Old World increased the probability of zoonotic pathogen transfer resulting in many human infectious crowd diseases such as measles, influenza, pertussis, diphtheria and smallpox (Diamond, 2002; Comas et al., 2013). These viral and bacterial infections spread to humans from epidemic diseases endemic to domestic (herd) animals, and depend on dense host populations in order to sustain themselves (Diamond, 2002). Also the altering dietary patterns and working habits emerging during the Neolithic revolution contributed to the changing epidemiology in the Old World. The greater health risk farmers were exposed to, therefore increased the interest in plants with medical values while, additionally, wild famine foods were important when the crop harvest failed. Brown (1985) pointed out that traditional agriculturalists distinguish generally more wild plant species than hunter-gatherers. Agriculturalists began to find their medicines among cultivated crops and wild food plants as well as the weedy flora adapted to the ecological niches created by their own activity (Logan and Dixon, 1994; Leonti et al., 2006). Out of the 25 major infectious diseases responsible for the highest mortality and morbidity in human history an unambiguous New World origin could only be established for Chagas' disease (Wolfe et al., 2007). For syphilis the situation remains unclear and the debate about its origin is ongoing (Wolfe et al., 2007) but historical data point towards a New World origin (Waugh, 1982; Mann, 1984, p. 215). There is supporting evidence that human tuberculosis originated in Africa over 70,000 years ago (Comas et al., 2013) yet the current Mycobacterium tuberculosis strains of the Americas are closely related to European strains (Bos et al., 2014). The analysis of $M$. tuberculosis genome found in pre-Columbian mummies suggests a zoonotic transfer from pinnipeds around 700 to $1000 \mathrm{CE}$, which presumably contracted $M$. tuberculosis from an African host and transferred the germs to South America (Bos et al., 2014). This would be compatible with the occurrence of pre-Columbian skeletal lesions attributed to M. tuberculosis infections (Bos et al., 2014). No data supporting any conclusion regarding their geographical origin are available for rotavirus, rubella, tetanus and typhus while for the other 18 pathogens an Old Word origin is almost certain (Wolfe et al., 2007). In contrast, agriculturalists and hunter-gatherers in the New World had to deal with fewer infectious diseases before the European Conquest, due to limited domestication of herd animals. Epidemiological data further suggest that Amerindian populations generally suffer a higher incidence of gastrointestinal problems, such as bile acid metabolism disorder, gallstone diseases, biliary tract and gallbladder cancer (Michaud, 2002; Shaffer, 2006). On top of that has the adoption of a westernized diet and life-style by Amerindian populations resulted in an increase in the prevalence of diabetes, obesity, hypertension and dyslipidemia and augmented the probability for contracting cardiovascular complications such as atherosclerosis and stroke (Broussard et al., 1991; Galloway, 2002). This seems to be associated with genes permitting an effective food metabolism (the so called "thrifty" genes), which are important for survival in nutritionally less predictable environments but become a risk factor when food becomes affluent (Hanis et al., 1986; Diamond, 2003). As a consequence, pre-Columbian traditional medicine is and was shaped by a different epidemiological context when compared to Old World medicine.

Moreover, the lack of written languages [the few surviving Maya codices are an exception] hampered the building of a large consensus about efficacious pre-Columbian medicines and reduced the possibility for cumulative knowledge transmission (see Lewis and Laland, 2012; and Leonti et al., 2015 for concept and mechanisms). Today some of the most widely used herbal remedies in rural areas and by indigenous groups in northern South America are introduced from Eurasia, Africa, North America and the Pacific (Bennett and Prance, 2000; see also Lorenzi and Matos, 2008). Although Leishmaniasis is endemic and native to tropical South America, for instance, many of the most frequently reported remedies from a cross-cultural analysis of 291 herbal species (Odonne et al., 2017) are cultivated or/and exotic.

It is, however, highly likely that, due to their more isolated subsistence, indigenous Amerindian groups show a much higher idiosyncrasy of native medicinal plant use (see e.g., Prance, 1973; Schultes and Raffauf, 1990; Milliken and Albert, 1996; Doyle, n.d.). During the last decades however, only few field studies have been conducted with indigenous Amerindian groups living in the Brazilian Amazon. This might be attributable to logistic issues and difficulties in obtaining permission from government agencies such as the FUNAI (Fundação Nacional do Índio) and the MMA (Ministério do Meio Ambiente).

\section{Development of pharmacopoeias with a focus on Europe}

\subsection{Origin and purpose of pharmacopoeias and the inclusion of exotic drugs}

Pharmacopoeias have their origin in local, regional and over-regional consensus collections of therapeutic knowledge about remedies derived from plant, animal, fungal and mineral origin. Such texts were called materia medica, then compositiones medicamentorum, antidotarii or dispensatorii, later on 'herbals' and finally 'pharmacopoeias' (Urdang, 1951) and testify to the early inclusion of exotic herbal drugs (Heffter, 1914). The first texts reproducing knowledge on materia medica (e.g., Ebers papyrus (ca. 16th century BCE, Egypt), Corpus Hippocraticum (Hippocrates and allies, 600-200 BCE, Greece), 'Enquiry into Plants' (Theophrastus, ca. 370-285 BCE, Greece), De Materia Medica (Dioscorides, 1st century CE, Greece), 'Shennong Bencaojing' (The Classic of Herbal Medicine, ca. 200-245 CE, China), the 'Bower Manuscript' (by Buddhist monks, ca. $600 \mathrm{CE}$, India)) were compiled on the perceived consensus of the therapeutic and commercial importance of the drugs used in a certain geographical area, and intended as a reference standard for medical doctors and their aspirants as well as those selling and compounding medicines (Urdang, 1951; Unschuld, 1986; Heinrich et al., 2004; Leonti and Verpoorte, 2017).

Today, the armamentarium of drug treatment is transmitted through 'pharmacopoeias', which are standard publications regulating the quality of pharmaceutical drugs, excipients and flavouring correctives, specifying their testing methods, purity, storage instructions, composition and concentration. Pharmacopoeias secure the uniformity of remedies approved by representatives of a specific political unit and make the quality standards obligatory (Urdang, 1951, p. 583). The 
usefulness of a pharmacopoeia (literally 'drug making') is “determined by the periodical changes it has to undergo to keep pace with the latest progress in the sciences on which it is based" (Urdang, 1951, p. 577). With respect to herbals, pharmacopoeias are distinguished in that they are legally binding quality standards and do not include therapeutic recommendations. This legally binding character has an imminent impact on the continuity of drug use. The pharmacopoeia of the city of Florence (Florentine 'Nuovo Receptario') from 1498 is regarded as the first official pharmacopoeia (Urdang, 1951; Corradi, 1966). Among the first true official state pharmacopoeias are the 'Ricettario Fiorentino' from 1573 (Grand Duchy of Tuscany) and the Pharmacopoeia Londinensis from 1618 (Realme of England) (Urdang, 1951).

In any event, the development of official pharmacopoeias was strongly influenced by the separation of medicine from pharmacy, a functioning public welfare system and the idea that the state is responsible for the health of its citizens (Urdang, 1951). A crucial step for the development of the European pharmacopoeias was the integration of indigenous drugs "discovered" during the colonial expansions of European kingdoms (e.g., Heffter, 1914, p. 16). The prospect of finding new medicines, new therapeutic solutions as well as spices was, in fact, an incentive for many conquerors and adventurers and resulted in a diversification of European materia medica and textbooks about exotic and indigenous drugs written by explorers, friars and commentators such as Garcia da Orta (1501-1568, 'Coloquios dos simples e drogas he cousas mediçinais da India' (India); da Orta, 1983), Nicolás Monardes (1574, 'Historia medicinal de las cosas que se traen de nuestras Indias Occidentales' (New World)), Francisco Hernández (1514-1587 'Historia Natural de Nueva España', (Mexico); Hernández, 1959-1967), de Saint Hilaire (1772-1844 'Plantes usuelles des Brésiliens', (Brazil); de Saint Hilaire, 2014), De Martius (1843, Systema materiae medicae vegetabilis Brasiliensis (Brazil)) and others (see Mann, 1984; Giorgetti et al., 2007; Brandão et al., 2012; Breitbach et al., 2013; Heinrich et al., 2014; Helmstädter, 2017; Leonti and Verpoorte, 2017; Rivera et al., 2017; Ricardo et al., 2018). This development culminated in the (transient) wealth of many European city-states depending on the herbal drug and spice trade (Tschirch, 1910). Moreover, from the 16th century onwards, herbal drugs have been cultivated wherever geographical, climatic and ecologic conditions allowed for economic production (Tschirch, 1910). Frequently the cultivations far from their native habitats were more productive as the pests and diseases were left behind (Prance, 2005 p. 28).

The many new herbal drugs and exotic plant species that arrived from overseas led to a rekindled interest in systematic botany and the attempt to systematize and assess the various herbal drugs used in folkmedicine in Europe and introduce them in medicine (Heffter, 1914 p. 16-17).

\subsection{Racial, nationalistic and economic considerations affecting the homogenization of pharmacopoeias}

Notwithstanding the increasing globalization and the synchronization of pharmacopoeias, which finally led to the European as well as the International Pharmacopoeia, the process was characterized by racial and political considerations as well as erroneous beliefs. According to Urdang (1951) "in earlier days ... it was thought that drugs originating in a certain country had an especially beneficial relation to the bodies of the residents of their common habitat" (Urdang, 1951, p. 583), which is also reflected in the introduction of the Pharmacopoeia Londinensis from 1618, which reads: "Why should not the citizens of London have their own? [Pharmacopoeia] ... the appreciation of which does not arise so much from its being precious, but from its being appropriate and welladapted to English bodies" (Urdang, 1951, p. 584). According to Heffter (1914, p. 17) already at the beginning of the 16th century in Germany and France the idea circulated that those plants, which grew underneath the hot sun would not be salubrious to inhabitants of the temperate zone while Paracelsus (1493-1541) as well as
Tabernaemontanus (1522-1590) thought that plants growing in a type of land and air are most beneficial to those, who were born and live there (Heffter, 1914, p. 17).

Similar ideas can still be found in recent articles, for example that by Pandalis and Keil (2014, p. 75), stating that "the concept explains why medications, which are proven for centuries are essential for health but exclusively within their respective ethno-context". This not only reminds us of gene polymorphism responsible for drug metabolism, but also of the concept of 'local biologies', referring to the fact that human biology shows universal and local characteristics (Niewöhner and Lock, 2018). A similar idea was the belief that the geographic origin of a disease would coincide with the origin of effective drugs (Mann, 1984). This makes sense in the light of a long bio-cultural interaction, i.e. a local trial and error approach to find appropriate drugs. Another factor that prevented the homogenization of pharmacopoeias were nationalistic ideologies and economic considerations leading to preferential inclusion of locally sourced and produced drugs on the expense of exotic drugs (Urdang, 1951). Urdang's (1951, p. 596) idealistic view of pharmacy is that in a similar fashion to medicine it is "an organized human attempt to meet elementary human needs not restricted to nationality, creed, or environment" and therefore "by its very nature international". Similarly, Tschirch $(2015$, p. 22$)$ noted in 1909, that "we don't ask anymore where a remedy is coming from but if it's effective".

Giving way to the pressure of global trade, can however, have an immediate impact on the inclusion of materia medica as the document A4-0075/97 by the European Parliament testifies: "The European Pharmacopoeia, as drawn up by the Council of Europe, needs to be opened up to other pharmacopoeiae particularly the medicinal plants used in Chinese medicine" (Bauer and Franz, 2010). Herbal drugs from other regions of the world, such as Ayurvedic or South American medicines, were not considered in this working programme (Bauer and Franz, 2010).

\subsection{Inclusion of exotic herbal drug monographs in Ph. Eur. 9.5}

Currently 219 herbal drug aggregates are listed in the Ph. Eur. 9.5 (2017), of which 97 (44\%) are native to Europe (and adjacent territories; sum of rows L-X in Table 1) and only 12 are from South America, four from Mesoamerica while two have a pantropic distribution (Fig. 1). As much as $81 \%$ (178; sum of rows G-J + sum of rows L-X in Table 1) of the herbal drug aggregates included in the Ph. Eur. 9.5 (2017) are native to Eurasia. The many Chinese herbal drug aggregates (ca. 30, of which currently 17 without an entry in the European Medicines Agency), which were continuously included beginning with Ph. Eur. 6 (Bauer and Franz, 2010) certainly contribute to this high share (see supplementary Table A). There is, however, also evidence pointing towards a more historical and geographical component regarding the inclusion of herbal drugs native to Eurasia: The vastness and the geographical extension (East-West axis) of Eurasia, with its almost identical day-lengths, seasons, climates, habitats and diseases, facilitated the successful exchange of a high diversity of useful germplasm, including that of herbal medicines, spices and food plants (e.g. Allium sativum, Brassica napus, Trigonella foenum-graecum, Coriandrum sativum, Triticum aestivum, Sesamum indicum, Carthamus tinctorius, Linum usitatissimum; see supplementary Table A). The North-South axis of the Americas in contrast worked as a factor complicating the exchange of valuable herbal species (see Diamond, 2002 for a more general discussion on this issue). This is also supported by the so-called Rapoport's rule asserting that while higher latitude species show larger geographical-range size, lower latitudes support more species (Stevens, 1989; and see Leonti et al., 2013 p. 102-103 for discussion related to plants used as medicine). The favourable conditions for exchanging germplasm of proven herbal drugs and spices as well as for commercializing herbal drugs across Eurasian cultures since ancient times facilitated therapeutic experimentations, the diversification of uses and the inclusion of 'exotic' drugs into local medicinal floras and pharmacopoeias. This historical 
legacy, deriving from the consensus around local medicinal systems across Eurasia and Northern Africa is also reflected in the Ph. Eur. 9.5 (2017).

\section{The contribution of pharmacognosy to the development of pharmacopoeias}

In a collaborative effort, during the 19th century, French and German chemists, physiologists and naturalists such as Alexander von Humboldt (1769-1859), Friedrich Sertürner (1783-1841), Joseph Pelletier (1788-1842), Claude Bernard (1813-1888), and others, conducted ethnopharmacological field studies, isolated pure active compounds and described their pharmacological effects (Bruneton, 1995, pp. 625-642; Heinrich et al., 2004; Gertsch, 2009). The coordinated interdisciplinary scientific investigations provided the necessary pharmacological and toxicological basis for the inclusion of pure chemical entities into the official pharmacopoeias (Heinrich et al., 2004; Wagner et al., 2007; Gertsch, 2009, and see also the different official pharmacopoeias). This development changed the character and composition of the pharmacopoeias. While, for example, the first German pharmacopoeia from 1872 contained 255 herbal drugs, the 5 th edition from 1910 included only 167 . In parallel the presence of chemical preparations increased from 53 in 1872 to 98 in 1910 (Heffter, 1914, p. 33). During the 19th and early 20th century pharmacognosy flourished in Germany (Heinrich and Anagnostou, 2017) resulting in innovative literature mostly published in German, which contextualized history of ethnomedicine with the latest discoveries in chemistry and pharmacology (e.g., Köhler, 1887; Lewin, 1894; Hartwich, 1897; Tschirch, 1909-1925). Similarly, the advancement of organic and natural product chemistry was mainly published in German during the 19th century (e.g., Liebig, 1837; Liebig und Geiger, 1843; von Hofmann, 1843; Kolbe, 1874; Baeyer, 1878). The chemical, pharmacological and toxicological characterization of the herbal drugs included in the European pharmacopoeias as well as the main medicinal plants used in Europe was still a major task of European pharmacognosists during the 1970s to the 1990s. As language is the main key in knowledge transmission, the instant access to the progresses in chemistry resulted in a strategic advantage of German-speaking scientists. Together with the establishment of scientific schools focusing on pharmacognosy and chemistry, and according to the principles of cultural evolution and knowledge transmission (see e.g. Cavalli-Sforza and Feldman, 1981; Diamond, 2005; Richerson and Christiansen, 2013), this allowed for a head start in central Europe and is part of the reason why the pharmaceutical (including those producing plant based medicines and nutraceuticals) and chemical industry is so well established in this European region still today (e.g. Novartis, Hoffman-La-Roche, Merck Serono, Clariant, Ciba, Lonza, DSM, Henkel, Hoechst, BASF, Bayer, Schwabe, Weleda).

7. Development of the Brazilian Pharmacopoeia, herbal products registered with ANVISA and plants used in popular and traditional medicine

\subsection{Development of the Brazilian Pharmacopoeia}

The Historia Naturalis Brasiliae written by the Dutch physician Willem Piso (1610-1678) and the German naturalist Georg Marcgraf (1610-1644) is the first scientific work about the natural world and traditional medical knowledge from Brazil (Françozo, 2010). The first pharmaceutical codex applied in colonial Brazil was, however, the 'General Pharmacopoeia for the Kingdom and Domains of Portugal' ('Farmacopeia Geral para o Reino e os Domínios de Portugal') by A. Tavares from 1794, and obligatory in Brazil from 1809 onwards. After gaining independence (1822), in addition, the French 'Codex Medicamentarius' (compulsory from 1851 onwards) was used by pharmacists. In 1882 it was established that the French Pharmacopoeia should be followed for the preparation of remedies, until the publication of the
Table 2

Number of monographs including herbal drug species in each edition of the official Brazilian Pharmacopoeia.

adopted from Brandão et al. (2006) and ANVISA (2010).

\begin{tabular}{llll}
\hline \multirow{2}{*}{ Edition } & \multicolumn{2}{l}{ Number (\%) of monographs } & \\
\cline { 2 - 4 } & Native & Others & Total \\
\hline $1^{\text {st }}$ edition (1929) & $196(27.5)$ & $517(72.5)$ & 713 \\
$2^{\text {st }}$ edition (1959) & $32(15.6)$ & $173(84.4)$ & 205 \\
$3^{\text {st }}$ edition (1977) & $4(17.4)$ & $19(82.6)$ & 23 \\
$4^{\text {st }}$ edition (1996) & $11(25)$ & $33(75)$ & 44 \\
$5^{\text {st }}$ edition (2010) & $15(26.9)$ & $41(73.1)$ & 56 \\
\hline
\end{tabular}

first Brazilian Pharmacopoeia, which saw light in 1929 (Pianetti, 2016). There exist five editions of the Brazilian Official Pharmacopoeia (FBRAS). The first was sanctioned in 1926 and published in 1929 ('Brazilian Pharmacopoeia Code - Pharmacopoeia of the United States of Brazil') while the current edition was published in 2010 replacing the previous 4 editions, which were all valid to this date (Pianetti, 2016). The initial adoption of European pharmacopoeias for sure consolidated the importance of exotic herbal drugs while the adoption of the French Pharmacopoeia appears like an attempt to shed off the colonial identity.

\subsection{Herbal drug monographs in the Brazilian Pharmacopoeia and the presence of exotic species}

In all its editions, the Brazilian Pharmacopoeia contained more exotic than native herbal drug species (Brandão et al., 2006; ANVISA, 2010). In parallel to the replacement of 'boticas' (herbal dispensatories) by pharmacies (drugstores) in succession of the isolation and synthesis of pure pharmaceutical compounds, the number of herbal drug monographs was drastically reduced in the first three editions of the Brazilian Pharmacopoeia (Brandão et al., 2006, Table 2). The share of native herbal drug monographs included in the Brazilian Pharmacopoeia has dropped from an initial $27.5 \%$ in 1929 to 15.6 and $17.4 \%$ in 1959 and 1977, respectively, but more recently (ANVISA, 2010, 5th edition) increased again to $26.9 \%$ corresponding to 15 species (Table 2; Fig. 2, supplementary table B).

The current fifth edition of the Brazilian Pharmacopoeia (ANVISA, 2010 "Farmacopoeia Brasileira, Vol. 2, Monografias 5 $5^{\mathrm{a}}$ edição") comprises only 55 herbal drug aggregates (see Table 3). The 359 herbal medicinal products licensed in Brazil contain herbal drugs derived from 101 different species (Carvalho et al., 2018). Of these "eight are native endemic, 19 are native non-endemic, six are naturalized, six are cultivated, and 62 are not originated in Brazil" (Carvalho et al., 2018). Since those cultivated and naturalized species are all exotic to Brazil of the 101 species, only 27 are native (27\%). Thus herbal drug species of products registered with ANVISA and those included in the Brazilian Pharmacopoeia are for the larger part exotic to Brazil (Table 3; Figs. 2 and 3). This was partially explained with the better documentations of efficacy and safety, as well as existing quality standard requirements and control protocols for non-native herbal drugs (Carvalho et al., 2018).

Thus, currently, and in spite of the higher biodiversity of Brazil with respect to Europe, the Brazilian Pharmacopoeia includes a considerably lower share of native species (ca. 27\%) when compared to the European Pharmacopoeia (44\%) (Figs. 1 and 2, Tables 1-3) and the number of licenced herbal medicines is relatively small when compared internationally (Carvalho et al., 2018).

Currently, among the 20 best-selling herbal medicines in Brazil, only one product derives from a species (Cordia curassavica (Jacq.) Roem. \& Schult., syn. Cordia verbenacea A.DC.) native to Brazil (Dutra et al., 2016) and among the 12 herbal medicines available through the public health care system in Brazil, 8 were developed from exotic plant species. These data are a reflection of the Brazilian herbal and 


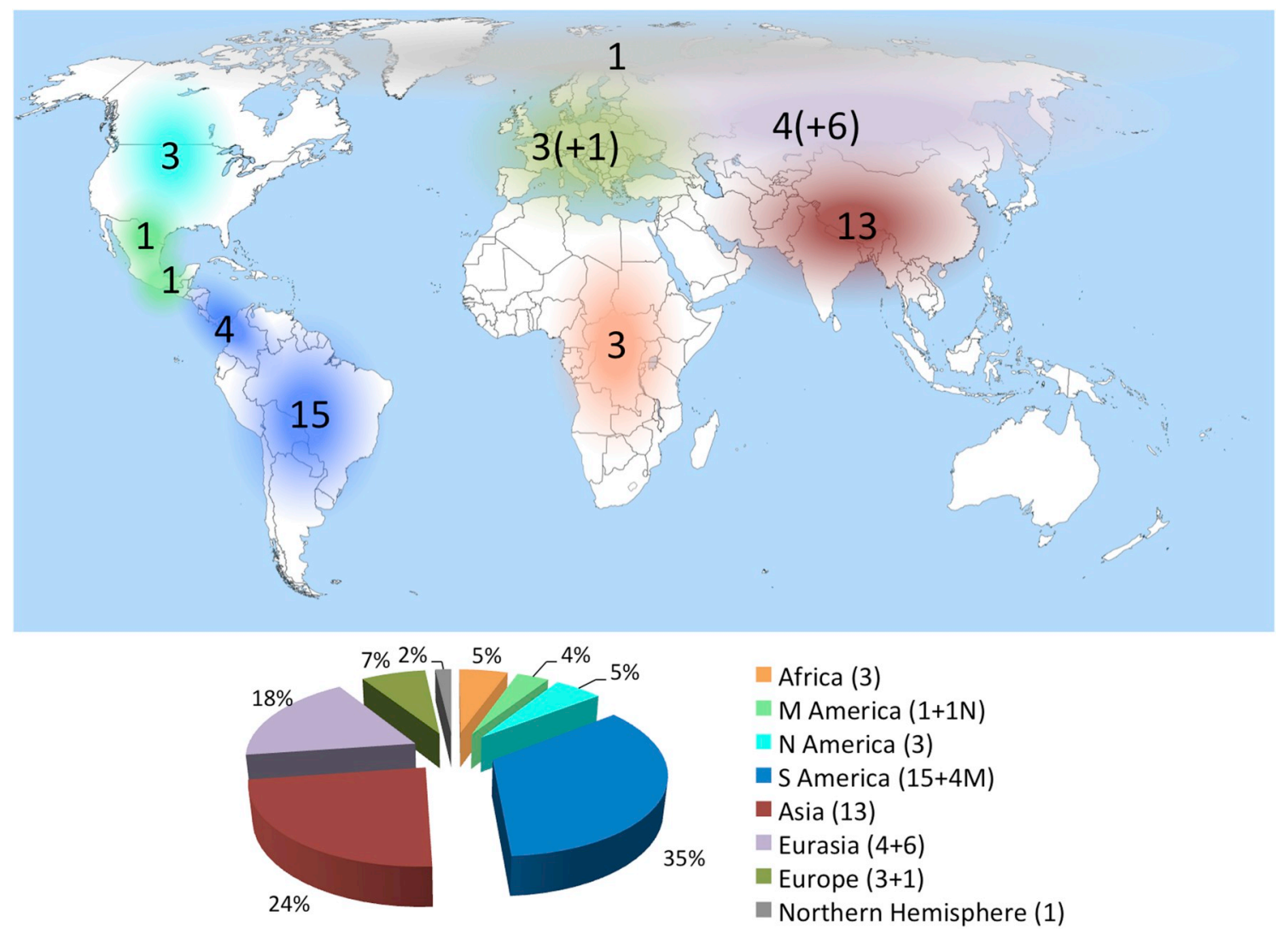

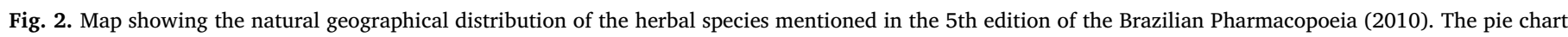
starts at 12:00 (Africa 5\%).

phytotherapeutic policies (BRASIL, 2006a, 2006b), notwithstanding that these claim ".... it prioritizes the biodiversity of the country [Brazil] ...”. Of the five main lists of medicinal plant species ${ }^{2}$ formulated by Brazilian government agencies aiming at encouraging the utilization, study and development of herbal medicines around 65\% are exotic (supplementary Table C). In line with these official documents, the 263 research groups working with medicinal plants (CNPq, 2018) and the pharmaceutical laboratories of Brazil developing herbal medicines pay little attention to native species of Brazil.

With the new patent law adopted in Brazil in 1996, an increase in the number of herbal medicines deriving from the Brazilian flora was expected but the registration process was afflicted with inefficiency and bureaucratic issues (Hasenclever et al., 2017). With the legalization of generic drugs in Brazil in 1999 the pharmaceutical industry concentrated their investments in the production and commercialization of generic drugs (Pontes, 2017). That only few native species are used for the production of herbal medicinal products in Brazil might also be associated with the restrictive framework regulating access to biodiversity from 2001 (Carvalho et al., 2018). The new law (n 13,123, May 2015) regulates research with biodiversity in Brazil as well as the access and protections of associated traditional knowledge in a more

\footnotetext{
21. Renisus (DAF, 2009), Anexo da RDC 10/2010 (revogada) [Annex of the RDC 10/2010 (retracted)] 2. Formulário de Fitoterápicos da Farmacopeia Brasileira (ANVISA, 2011) [Schedule of phytotherapeutics of the Brazilian Pharmacopoeia (ANVISA, 2011)] 3. Relação Nacional de Medicamentos Essenciais (RENAME, 2015) [National Relation of Essential Medicines (RENAME/ 2015)] 4. Memento Fitoterápico da Farmacopeia Brasileira (ANVISA, 2016) [Phytotherapeutic notes of the Brazilian Pharmacopoeia] and 5. Formulário de Fitoterápicos da Farmacopeia Brasileira - Primeiro Suplemento (ANVISA, 2018) [Schedule of phytotherapeutics of the Brazilian Pharmacopoeia, First Supplement].
}

transparent way specifying benefit-sharing mechanisms. Moreover, in a process aligning the Brazilian legislation with international standards, next to "herbal medicines", for which clinical and non-clinical trials are mandatory for registration, now also "traditional herbal products" are distinguished, for which the documented traditional use (at least 30 years) is regarded as a proxy for safety and effectiveness (Carvalho et al., 2018). This simplification for licencing herbal medicinal products is expected to lead to new registrations making use of local traditional herbal practices.

For example, of the 335 plant species presented in the book 'Plantas Medicinais no Brasil' by Lorenzi and Matos (2008) 135 are exotic and $200(60 \%)$ are native. In total 177 native species, which are referenced by Lorenzi and Matos (2008) and used in traditional and folk medicine in Brazil, are neither part of licenced products nor included in the Brazilian Pharmacopoeia (Fig. 3). Only 12 herbal drug species (4 of them native) are simultaneously contained in the Brazilian Pharmacopoeia, present among the herbal medicinal products licensed and included in the book by Lorenzi and Matos (2008; Fig. 3, Table 3). As many ethnopharmacological field studies have shown, the herbal knowledge of people and communities in Brazil exceeds by far the herbal knowledge described in Lorenzi and Matos (2008).

\section{Conclusions}

Notwithstanding the higher biodiversity of Brazil with respect to Europe, the Brazilian Pharmacopoeia includes a considerably lower share of native herbal drugs when compared to the European Pharmacopoeia. We associate this discrepancy to several factors linked with biogeographic preconditions, disparate historical developments of medicine and pharmacy as well as cultural evolution at large. Accumulated evidence suggests that at the time of the Conquest the epidemiology of the Amerindian populations resembled more that of 
Table 3

Herbal species mentioned in the 5th edition of the Brazilian Pharmacopoeia (2010), herbal species present in products registered with ANVISA (A) and herbal species popularly used as medicine in Brazil according to Lorenzi and Matos (2008; L).

\begin{tabular}{|c|c|c|c|c|c|c|}
\hline Herbal taxon & Family & Drug & Portuguese/popular & $\mathrm{N} / \mathrm{E}$ & A & $\mathrm{L}$ \\
\hline Aesculus hippocastanum L. & Hippocastanaceae & Hippocastani semen & Castanha-da-Índia & $\mathrm{E}$ & $\mathrm{x}$ & \\
\hline Anethum graveolens L. & Apiaceae & Anethi fructus & Endro & $\mathrm{E}$ & & \\
\hline Arachis hypogaea L. & Fabaceae & Arachidis oleum & Óleo-de-amendoim & $\mathrm{E}$ & & \\
\hline Arnica montana L. & Asteraceae & Arnicae flos & Arnica & $\mathrm{E}$ & $\mathrm{x}$ & \\
\hline Atropa belladonna L. & Solanaceae & Belladonnae folium & Beladona & $\mathrm{E}$ & $\mathrm{x}$ & \\
\hline Baccharis trimera (Less.) DC. (Syn. Baccharis crispa Spreng.) & Asteraceae & Baccharis trimerae herbae & Carqueja, carqueja-amarga & $\mathrm{N}$ & & $\mathrm{x}$ \\
\hline Calendula officinalis $\mathrm{L}$. & Asteraceae & Calendulae flos & Calêndula & $\mathrm{E}$ & $\mathrm{x}$ & $\mathrm{x}$ \\
\hline Centella asiatica (L.) Urban & Apiaceae & Centellae folium & Centela & $\mathrm{E}$ & $\mathrm{x}$ & $\mathrm{x}$ \\
\hline Cinchona calisaya Weddell & Rubiaceae & Cinchonae cortex & Quina-amarela & $\mathrm{E}$ & $\mathrm{x}$ & $\mathrm{x}$ \\
\hline Cinnamomum cassia (L.) J. Presl & Lauraceae & Cinnamomi cortex & Canela-da-China & $\mathrm{E}$ & & \\
\hline Cinnamomum verum J. Presl & Lauraceae & Cinnamomi cortex & Canela-do-Ceilão & $\mathrm{E}$ & $\mathrm{x}$ & $\mathrm{x}$ \\
\hline Citrus aurantium L. subsp. aurantium & Rutaceae & Aurantii amari exocarpium & Laranja-amarga & $\mathrm{E}$ & & $\mathrm{x}$ \\
\hline Cola nitida (Vent.) A.Chev & Sterculiaceae & Colae semen & Noz-de-cola & $\mathrm{E}$ & & \\
\hline Crataegus spp. & Rosaceae & Crataegi folium cum flore & Cratego & $\mathrm{E}$ & $\mathrm{x}$ & \\
\hline Curcuma longa $\mathrm{L}$. & Zingiberaceae & Curcumae longae rhizome & Cúrcuma & $\mathrm{E}$ & $\mathrm{x}$ & $\mathrm{x}$ \\
\hline Cymbopogon citratus (DC.) Stapf & Poaceae & Cymbopogonis foliae & $\begin{array}{l}\text { Capim-limão, Capim-cidró, } \\
\text { Capim-santo }\end{array}$ & $\mathrm{E}$ & & $\mathrm{x}$ \\
\hline Datura stramonium L. & Solanaceae & Stramonii folium & Estramônio & $\mathrm{E}$ & & $\mathrm{x}$ \\
\hline Echinodorus grandiflorus (Cham. \& Schltdl.) Micheli & Alismataceae & Echinodorus folium & Chapéu-de-couro & $\mathrm{N}$ & & $\mathrm{x}$ \\
\hline Elettaria cardamomum (L.) Maton & Zingiberaceae & Cardamomi semen & Cardamomo & $\mathrm{E}$ & & \\
\hline Eugenia uniflora L. & Myrtaceae & Eugeniae folium & Pitangueira & $\mathrm{N}$ & & $\mathrm{x}$ \\
\hline Gentiana lutea $\mathrm{L}$. & Gentianaceae & Gentianae rhizoma et radix & Genciana & $\mathrm{E}$ & $\mathrm{x}$ & \\
\hline Hamamelis virginiana $\mathrm{L}$. & Hamamelidaceae & Hamamelidis tinctura & Tintura de hamamélis & $\mathrm{E}$ & $\mathrm{x}$ & \\
\hline Hydrastis canadensis $\mathrm{L}$. & Ranunculaceae & Hydrastidis radix & Hidraste & $\mathrm{E}$ & & \\
\hline Hyoscyamus niger $\mathrm{L}$. & Solanaceae & Hyoscyami folium & Meimendro & $\mathrm{E}$ & & \\
\hline Illicium verum Hook. $\mathrm{f}$. & Magnoliaceae & Anisi stellati fructus & $\begin{array}{l}\text { Anis-estrelado, badiana, } \\
\text { badiana-da-China }\end{array}$ & $\mathrm{E}$ & & \\
\hline Krameria triandra Ruiz \& Pav. & Krameriaceae & Ratanhiae radix & Ratânia & $\mathrm{E}$ & & \\
\hline $\begin{array}{l}\text { Maytenus ilicifolia Mart. ex Reissek (Syn. Monteverdia } \\
\text { ilicifolia (Mart. ex Reissek) Biral) }\end{array}$ & Celastraceae & Mayteni folium & Espinheira-santa & $\mathrm{N}$ & $\mathrm{x}$ & $\mathrm{x}$ \\
\hline Melissa officinalis L. & Lamiaceae & Melissae folium & Melissa & $\mathrm{E}$ & $\mathrm{x}$ & $\mathrm{x}$ \\
\hline Mentha $x$ piperita $\mathrm{L}$. & Lamiaceae & $\begin{array}{l}\text { Menthae piperitae folium, Menthae } \\
\text { piperitae aetheroleum }\end{array}$ & $\begin{array}{l}\text { Hortelã-pimenta, } \\
\text { Óleo essencial de hortelã- } \\
\text { pimenta }\end{array}$ & $\mathrm{E}$ & & $\mathrm{x}$ \\
\hline $\begin{array}{l}\text { Myroxylon balsamum (L.) Harms and Myroxylon balsamum } \\
\text { var. pereirae (Royale) Harms }\end{array}$ & Fabaceae & Balsamum tolutanum & Bálsamo-de-tolu & $\mathrm{N}$ & $\mathrm{x}$ & $\mathrm{x}$ \\
\hline $\begin{array}{l}\text { Myroxylon balsamum (L.) Harms var. pereirae (Royle) } \\
\text { Harms }\end{array}$ & Fabaceae & Balsamum peruvianum & Bálsamo-de-Peru & $\mathrm{E}$ & & \\
\hline Olea europaea L. & Oleaceae & Olivae oleum virginum & Azeite de oliva & $\mathrm{E}$ & & \\
\hline Passiflora alata Curtis & Passifloraceae & Passiflorae dulcis folium & Maracujá-doce & $\mathrm{N}$ & $\mathrm{x}$ & \\
\hline Passiflora edulis Sims & Passifloraceae & Passiflorae acetum folium & Maracujá-azedo & $\mathrm{N}$ & $\mathrm{x}$ & $\mathrm{x}$ \\
\hline Paullinia cupana Kunth & Sapindaceae & Paulliniae semen & Guaraná & $\mathrm{N}$ & $\mathrm{x}$ & $\mathrm{x}$ \\
\hline Persea americana Mill. & Lauraceae & Persea folium & Abacateiro & $\mathrm{E}$ & $\mathrm{x}$ & $\mathrm{x}$ \\
\hline Peumus boldus Molina & Monimiaceae & Boldus folium & Boldo & $\mathrm{E}$ & $\mathrm{x}$ & \\
\hline Phyllanthus niruri L. & Phyllanthaceae & Phyllanthus niruri herbae & Quebra-piedra & $\mathrm{N}$ & & $\mathrm{x}$ \\
\hline Phyllanthus tenellus Roxb & Phyllanthaceae & Phyllanthus tenellus herbae & Quebra-piedra & $\mathrm{N}$ & & \\
\hline Pilocarpus microphyllus Stapf & Rutaceae & Jaborandi tinctura & Tintura de jaborandi & $\mathrm{N}$ & & $\mathrm{x}$ \\
\hline Pimpinella anisum $\mathrm{L}$. & Apiaceae & Anisi fructus & Anis-doce, Erva-doce & $\mathrm{E}$ & & $\mathrm{x}$ \\
\hline Polygala senega L. & Polygalaceae & Senegae radix & Polígala & & $\mathrm{x}$ & \\
\hline Quillaja saponaria Molina & Quillajaceae & Quillaiae cortex & Quilaia & $\mathrm{E}$ & & \\
\hline Rauvolfia serpentina (L.) Benth. ex Kurz & Apocynaceae & Rauvolfi ae radix & Rauvolfia & $\mathrm{E}$ & & \\
\hline Rheum palmatum L. and/or Rheum officinale Baill. & Polygonaceae & Rhei rhizoma et radix & Ruibarbo & $\mathrm{E}$ & $\mathrm{x}$ & \\
\hline Rosmarinus officinalis $\mathrm{L}$. & Lamiaceae & Oleum rosmarini aetheroleum & Óleo essencial de alecrim & $\mathrm{E}$ & & $\mathrm{x}$ \\
\hline Salix alba L. & Salicaceae & Salicis cortex & Salgueiro-branco & $\mathrm{E}$ & $\mathrm{x}$ & \\
\hline Sambucus australis Cham. \& Schltdl & Caprifoliaceae [Adoxaceae] & Sambucus australis flos & Sabugueiro-do-Brazil & $\mathrm{N}$ & & $\mathrm{x}$ \\
\hline Sambucus nigra L. & Caprifoliaceae [Adoxaceae] & Sambucus nigra flos & Sabugueiro & $\mathrm{E}$ & & \\
\hline Senna alexandrina Mill. & Fabaceae & Sennae folium & Sene & $\mathrm{E}$ & $\mathrm{x}$ & \\
\hline Sesamum indicum $\mathrm{L}$. & Pedaliaceae & Sesami oleum & Óleo-de-gergelim & $\mathrm{E}$ & & $\mathrm{x}$ \\
\hline Stevia rebaudiana (Bertoni) Bertoni & Asteraceae & Steviae folium & Estévia & $\mathrm{N}$ & & $\mathrm{x}$ \\
\hline Stryphnodendron adstringens (Mart.) Coville & Fabaceae & Barbadetimani cortex & Barbatimão & $\mathrm{N}$ & $\mathrm{x}$ & $\mathrm{x}$ \\
\hline $\begin{array}{l}\text { Styrax benzoin Dryander or Styrax paralleloneuron } \\
\quad \text { Perkins }\end{array}$ & Styracaceae & Benzoe sumatranus & Benjoim & $\mathrm{E}$ & & \\
\hline Vanilla planifolia Andrews & Orchidaceae & Vanillae fructus & Baunilha & $\mathrm{N}$ & & \\
\hline
\end{tabular}

N: Native to Brazil; E: Exotic to Brazil; A: ANVISA (Carvalho et al., 2018); L: Lorenzi and Matos (2008).

pre-agriculturalist societies, while no written consensus around efficacious medicine existed. The trial and error approach using biodiversity for the treatment of infections and symptoms associated with crowd diseases seems to have begun in the Americas only after the Conquest. Consequently, the time local medicines in the New World were empirically tested for the treatment of these frequent afflictions was inferior when compared to Eurasia and Africa. The East-West orientation of Eurasia facilitated the successful exchange of germplasm of welltried plant species over wide areas and the building of a consensus around efficacious medicine. On the other hand did the high species richness in the Neotropics together with the lack of written languages aggravate the exchange and conservation of knowledge. After the 


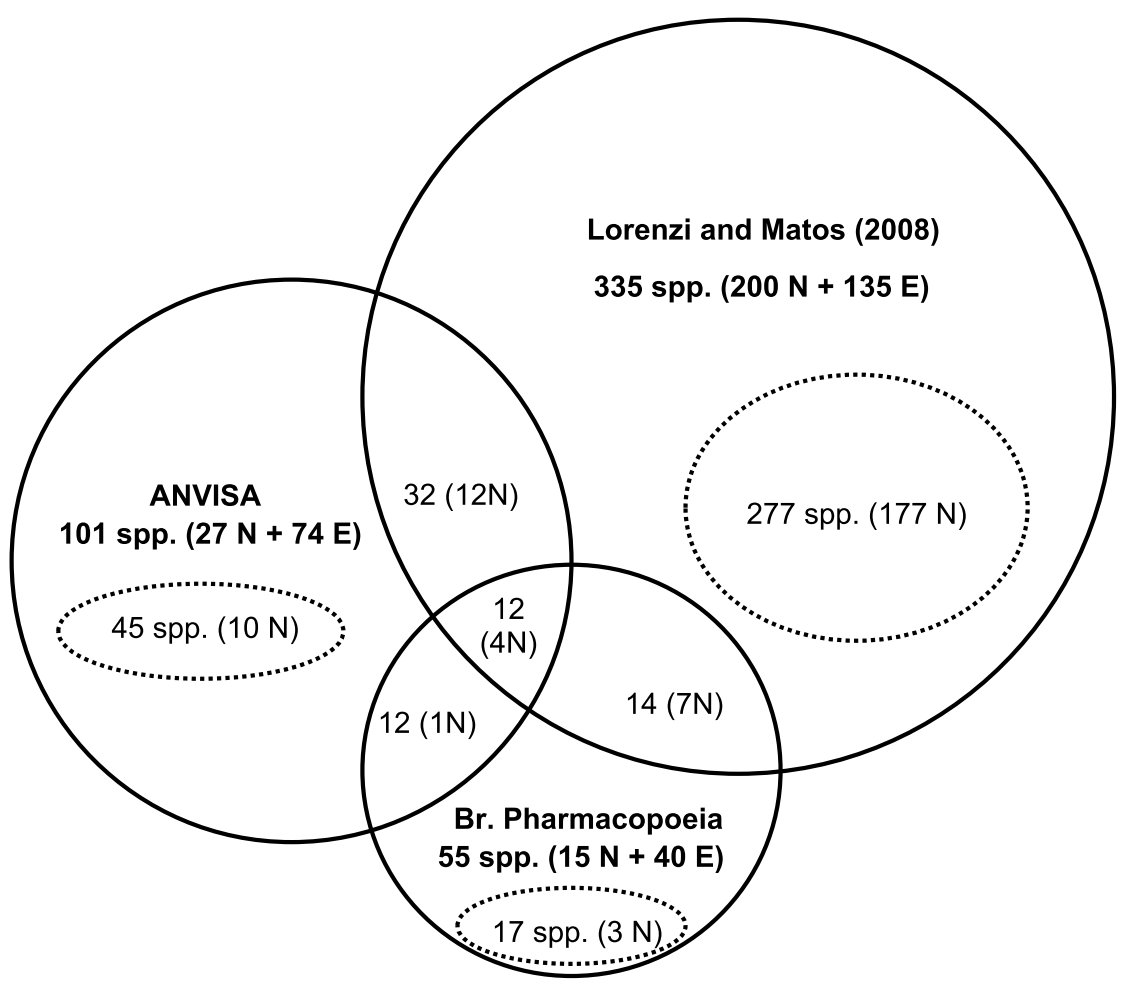

Fig. 3. Overlap between the herbal species included in the Brazilian pharmacopoeia, those used for products registered with ANVISA (see Carvalho et al., 2018) and those mentioned in Lorenzi and Matos (2008). N = Native; $\mathrm{E}=$ Exotic. The numbers within the doted circles refer to taxa not included in the other 2 sources, respectively.

colonization of the New World introduced and proven plant species empirically tested over millennia in the Old World gained therapeutic importance in the New World. Meanwhile the longstanding and cumulative pharmacognostic research activities in Europe and the USA focusing on the herbal drugs important in their pharmacopoeias resulted in an accumulation of herbal drugs with the status as safe and efficacious persisting in pharmacopoeias. The ethnopharmacological field studies conducted in the Neotropics are useful for highlighting consensus around the use of herbal medicines but seem to not have been able to include much data from Amerindian communities living in the Amazon in the past decades. This results often in studies lacking novelty reporting common herbal drug species, whether native or introduced. After the boom of the pharmaceutical industry resulting from the legalization of generic drugs, herbal medicinal products deriving from local biodiversity could represent timely and innovative products for investing the generated profits. Newly adopted regulations regarding access to biodiversity and traditional knowledge as well as the simplified procedure for licencing herbal medicinal products in Brazil prospects an interesting future for ethnopharmacologists and those aiming at developing herbal medicine based on bio-cultural diversity.

\section{Appendix A. Supplementary data}

Supplementary data to this article can be found online at https:// doi.org/10.1016/j.jep.2019.111891.

\section{References}

Ajaiyeoba, E.O., Abalogu, U.I., Krebs, H.C., Oduola, A.M.J., 1999. In vivo antimalarial activities of Quassia amara and Quassia undulata plant extracts in mice. J. Ethnopharmacol. 67, 321-325.

Anonymous, 1884. Farmacopea Oficial Española. 6a Edición. Tipografía de Gregorio Estrada, Madrid.

Antonelli, A., Sanmartín, I., 2011. Why are there so many plant species in the Neotropics? Taxon 60, 403-414.

ANVISA, 2010. Farmacopoeia Brasileira - Volum 2 - Monografias $5^{\mathrm{a}}$ edição 2010. Agência Nacional de Vigilância Sanitária Fundação Oswaldo Cruz. Brasília. www.anvisa.gov. br, Accessed date: 12 April 2019.

ANVISA, 2011. Formulário de Fitoterápicos da Farmacopeia Brasileira) [Schedule of phytotherapeutics of the Brazilian Pharmacopoeia. ANVISA 2011.
ANVISA, 2016. Memento Fitoterápico da Farmacopeia Brasileira [Phytotherapeutic notes of the Brazilian Pharmacopoeia. ANVISA 2016.

ANVISA, 2018. Formulário de Fitoterápicos da Farmacopeia Brasileira - Primeiro Suplemento [Schedule of phytotherapeutics of the Brazilian Pharmacopoeia, First Supplement. ANVISA 2018.

Baeyer, A., 1878. Synthese des Indigoblaus. Ber. Dtsch. Chem. Ges. 11, 1296-1297.

Bauer, R., Franz, G., 2010. Modern European monographs for quality control of Chinese herbs. Planta Med. 76, 2004-2011.

Bennett, B.C., Prance, G.T., 2000. Introduced plants in the indigenous pharmacopoeia of northern South America. Econ. Bot. 54, 90-102.

Bertani, S., Houël, E., Stien, D., Chevolot, L., Jullian, V., Garavito, G., Bourdy, G., Deharo, E., 2006. Simalikalactone D is responsible for the antimalarial properties of an Amazonian traditional remedy made with Quassia amara L. (Simaroubaceae). J. Ethnopharmacol. 108, 155-157.

Bieski, I.G., Leonti, M., Arnason, J.T., Ferrier, J., Rapinski, M., Violante, I.M., Balogun, S.O., Pereira, J.F., Figueiredo, R. de C., Lopes, C.R., da Silva, D.R., Pacini, A., Albuquerque, U.P., Martins, D.T., 2015. Ethnobotanical study of medicinal plants by population of valley of Juruena region, legal Amazon, Mato Grosso, Brazil. J. Ethnopharmacol. 173, 383-423.

Bigelow, J., 1822. A Treatise on the Materia Medica: Intended as a Sequel to the Pharmacopoeia of the United States: Being an Account of the Origin, Qualities and Medical Uses of the Articles and Compounds, Which Constitute that Work, with Their Modes of Prescription and Administration. C. Ewer, Boston.

Bos, K.I., Harkins, K.M., Herbig, A., Coscolla, M., Weber, N., Comas, I., Forrest, S.A., Bryant, J.M., Harris, S.R., Schuenemann, V.J., Campbell, T.J., Majander, K., Wilbur, A.K., Guichon, R.A., Wolfe Steadman, D.L., Cook, D.C., Niemann, S., Behr, M.A., Zumarraga, M., Bastida, R., Huson, D., Nieselt, K., Young, D., Parkhill, J., Buikstra, J.E., Gagneux, S., Stone, A.C., Krause, J., 2014. Pre-Columbian mycobacterial genomes reveal seals as a source of New World human tuberculosis. Nature 514, 494-497.

Bourdy, G., Aubertin, C., Jullian, V., Deharo, E., 2017. Quassia "biopiracy" case and the Nagoya Protocol: a researcher's perspective. J. Ethnopharmacol. 206, 290-297.

Brandão, M.G.L., Cosenza, G.P., Moreira, R.A., Monte-Mór, R.L., 2006. Medicinal plants and other botanical products from the Brazilian Official Pharmacopoeia. Rev. Bras. Farmacogn. 16, 408-420.

Brandão, M.G., Zanetti, N.N., Oliveira, P., Grael, C.F., Santos, A.C., Monte-Mór, R.L., 2008. Brazilian medicinal plants described by 19 th century European naturalists and in the Official Pharmacopoeia. J. Ethnopharmacol. 120, 141-148.

Brandão, M.G., Pignal, M., Romaniuc, S., Grael, C.F., Fagg, C.W., 2012. Useful Brazilian plants listed in the field books of the French naturalist Auguste de Saint-Hilaire (1779-1853). J. Ethnopharmacol. 143, 488-500.

BRASIL, 2006a. Ministério da Saúde. Secretaria de Atenção à Saúde. Departamento de Atenção Básica. Política Nacional de Práticas Integrativas e Complementares no SUS PNPIC-SUS/Ministério da Saúde, Secretaria de Atenção à Saúde, Departamento de Atenção Básica. Ministério da Saúde, Brasília.

BRASIL, 2006b. Presidência da República. Decreto 5.813, de 22 de junho de 2006. Política Nacional de Plantas Medicinais e Fitoterápicos. Diário Oficial da União, Brasília, DF, 23 jun.

Breitbach, U.B., Niehues, M., Lopes, N.P., Faria, J.E., Brandão, M.G., 2013. Amazonian 
Brazilian medicinal plants described by C.F.P. von Martius in the 19th century. J. Ethnopharmacol. 147, 180-189.

Broussard, B.A., Johnson, A., Himes, J.H., Story, M., Fichtner, R., Hauck, F., BachmanCarter, K., Hayes, J., Frohlich, K., Gray, N., et al., 1991. Prevalence of obesity in American Indians and Alaska natives. Am. J. Clin. Nutr. 53, 1535S-1542S.

Brown, C.H., 1985. Mode of subsistence and folk biological taxonomy. Curr. Anthropol. 26, 43-64.

Bruneton, J., 1995. Pharmacognosy, Phytochemistry, Medicinal Plants. Lavoisier Publishing, Paris.

Carvalho, A.C.B., Lana, T.N., Perfeito, J.P.S., Silveira, D., 2018. The Brazilian market of herbal medicinal products and the impacts of the new legislation on traditional medicines. J. Ethnopharmacol. 212, 29-35.

Castañeda-Gómez, J., Pereda-Miranda, R., 2011. Resin glycosides from the herbal drug jalap (Ipomoea purga). J. Nat. Prod. 74, 1148-1153.

Cavalli-Sforza, L.L., Feldman, M.W., 1981. Cultural Transmission and Evolution: A Quantitative Approach. Monographs in Population Biology, vol. 16 Princeton University Press, New Jersey.

Christison, R., 1842. A Dispensatory, or Commentary on the Pharmacopoeias of Great Britain: Comprising the Natural History, Description, Chemistry, Pharmacy, Actions, Uses, and Doses of the Articles of the Materia Medica. Black.

CNPq, 2018. Conselho Nacional de Desenvolvimento Científico e Tecnológico. Diretório de Grupos de Pesquisa no Brasil. http://dgp.cnpq.br/buscagrupo/, Accessed date: 27 August 2018.

Comas, I., Coscolla, M., Luo, T., Borrell, S., Holt, K.E., Kato-Maeda, M., Parkhill, J., Malla, B., Berg, S., Thwaites, G., Yeboah-Manu, D., Bothamley, G., Mei, J., Wei, L., Bentley, S., Harris, S.R., Niemann, S., Diel, R., Aseffa, A., Gao, Q., Young, D., Gagneux, S., 2013. Out-of-Africa migration and Neolithic coexpansion of Mycobacterium tuberculosis with modern humans. Nat. Genet. 45, 1176-1182.

Corradi, A., 1966. Le prime farmacopee Italiane ed in particolare dei ricettari fiorentini. Fratelli Rechiedei Editori, Milano.

Cullen, W., 1789. A treatise of the materia medica: by william Cullen. In: Two Volumes, vol. 2 Printed for Charles Elliot, Edinburgh.

da Orta, G., 1983. Coloquios dos simples, e drogas he cousas mediçinais da India, e assi dalgunas frutas achadas nella onde se tratam algunas cousas tocantes amediçina, pratica, e outras cousas boas, pera saber compostos pello Doutor garçia dorta: fisico del Rey nosso senhor, vistos pello muyto Reuerendo senhor, ho liçençiado Alexos diaz: falcam desenbargador da casa sa supricaçan inquisidor nestas partes. Com priuilegio do Condeviso Rey. por Ioannes de endem. Reprinted. Casa da Moeda, Lisboa (1983).

DAF, 2009. RDC, 2010. Renisus Annex 10/2010 (retracted).

De Martius, K.F.P., 1843. Systema Materiae Medicae Vegetabilis Brasiliensis. Apud Fleischer F., Leipzig.

De Saint Hilaire, A., 2014. Plantas Usuais Dos Brasileiros. Edtrs. Pignal, M., Lins Brandão, M.G. Fino Traco Editora. Belo Horizonte.

Diamond, J., 2002. Evolution, consequences and future of plant and animal domestication. Nature 418, 700-707.

Diamond, J., 2003. The double puzzle of diabetes. Nature 423, 599-602.

Diamond, J., 2005. Guns, Germs, and Steel. The Fates of Human Societies. W.W. Norton and Company, New York/London.

Doyle, M. (n.d.) Aspects of Baniwa Medicinal Flora and Ethno-Ecology. Research Report, Fundação Universidade Amazonas, Manaus, Brazil.

Duncan, A., 1803. The Edinburgh New Dispensatory: Illustrated with Tables. Bell et Bradfute.

Dutra, R.C., Campos, M.M., Santos, A.R., Calixto, J.B., 2016. Medicinal plants in Brazil: pharmacological studies, drug discovery, challenges and perspectives. Pharmacol. Res. 112, 4-29.

Eich, E., 2008. Secondary Metabolites Derived from Fatty Acids and Carbohydrates. Solanaceae and Convolvulaceae: Secondary Metabolites: Biosynthesis, Chemotaxonomy, Biological and Economic Significance (A Handbook). pp. 525-582.

European Pharmacopoeia, 2017. index. https://www.edqm.eu/sites/default/files/ supplement95e-latinindex-november2017.pdf 9.5 .

Evans, W.C., Evans, D., Trease, G.E., 2009. Trease and Evans Pharmacognosy, sixteenth ed. Saunders/Elsevier, Edinburgh, New York.

FCP (Fundação Cultural Palmares), 2019. http://www.palmares.gov.br/?page_id= 37551, Accessed date: 12 April 2019.

Felter, H.W., Lloyd, J.U., 1898. King's American Dispensatory. Eclectic Medical Publications. Ohio Valley Co., Cincinnati.

Françozo, M., 2010. Alguns comentários à Historia Naturalis Brasiliae. Cadernos de Etnolingu"ística 2 (1) fev/2010.

Galloway, J.M., 2002. The epidemiology of atherosclerosis and its risk factors among Native Americans. Curr. Diabetes Rep. 2, 274-281.

Gates, W., 2000. An Aztec Herbal. The Classic Codex of 1552. Dover, New York.

Geck, M.S., Reyes García, A.J., Casu, L., Leonti, M., 2016. Acculturation and ethnomedicine: a regional comparison of medicinal plant knowledge among the Zoque of southern Mexico. J. Ethnopharmacol. 187, 146-159.

Gertsch, J., 2009. How scientific is the science in ethnopharmacology? Historical perspectives and epistemological problems. J. Ethnopharmacol. 122, 177-183.

Giorgetti, M., Negri, G., Rodrigues, E., 2007. Brazilian plants with possible action on the central nervous system. A study of historical sources from the 16th to 19th century. J. Ethnopharmacol. 109, 338-347.

Gray, S.F., 1821. A Supplement to the Pharmacopoeia: Being a Treatise on Pharmacology in General; Including Not Only the Drugs and Compounds Which Are Used by Practitioners of Medicine, but Also Those Which Are Sold by Chemists, Druggists, and Herbalists for Other Purposes; Together with a Collection of the Most Useful Medical Formulae. Printed for Thomas and George Underwood, London.

Hanis, C.L., Chakraborty, R., Ferrell, R.E., Schull, W.J., 1986. Individual admixture estimates: disease associations and individual risk of diabetes and gallbladder disease among Mexican-Americans in Starr County, Texas. Am. J. Phys. Anthropol. 70, 433-441.

Hartwich, C., 1897. Die Neuen Arzneidrogen Aus Dem Pflanzenreiche. Verlag von Julius Springer, Berlin.

Hasenclever, L., Paranhos, J., Costa, C.R., Cunha, G., Vieira, D., 2017. A indústria de fitoterápicos brasileira: desafios e oportunidades. Ciênc. saúde colet. 22, 2559-2569.

Healde, T., Latham, J., 1793. The Pharmacopoeia of the Royal College of Physicians of London. Longman.

Heffter, A., 1914. Die Auffindung von Arzneimitteln. Festrede gehalten am Stiftungstage der Kaiser Wilhelms-Akademie für das Militärärtzliche Bildungswesen, vol. 2 Verlag von August Hirschwald, Berlin Dezember 1913.

Heinrich, M., Anagnostou, S., 2017. From pharmacognosia to DNA-based medicinal plant authentication - pharmacognosy through the centuries. Planta Med. 83, 1110-1116.

Heinrich, M., Barnes, J., Gibbons, S., Williamson, E.M., Edtrs, 2004. Fundamentals of Pharmacognosy and Phytotherapy. Churchill Livingstone, London.

Heinrich, M., Frei Haller, B., Leonti, M., 2014. A perspective on natural products research and ethnopharmacology in Mexico: the eagle and the serpent on the prickly pear cactus. J. Nat. Prod. 77, 678-689.

Helmstädter, A., 2017. The botanical explorer's legacy: a promising bioprospecting tool. Drug Discov. Today 22, 757-760.

Hernández, F., 1959. Historia Natural de Nueva España. Universidad Nacional Autónoma de México Vol. II, Mexico City.

Hernández, F., 1959-1967. Historia natural de Nueva España. Universidad Nacional Autónoma de México. Cuatro tomos, México.

Hubbell, S.P., He, F., Condit, R., Borda-de-Agua, L., Kellner, J., Ter Steege, H., 2008. Colloquium paper: how many tree species are there in the Amazon and how many of them will go extinct? Proc. Natl. Acad. Sci. U.S.A. 105 (Suppl. 1), 11498-11504.

IBGE (Instituto Brasileiro de Geografia e Estatística) https://censo2010.ibge.gov.br/ noticias-censo $\cdot$ html busca $=1 \& \mathrm{id}=3 \&$ idnoticia $=2194 \& \mathrm{t}=$ censo-2010-populacaoindigena-896-9-mil-tem-305-etnias-fala-274\&view = noticia, Accessed date: 12 October 2019

ISA, 2019. (Instituto Socioambiental), Índios do Brasil. https://pib.socioambiental.org/ pt/Quantos s\%C3\%A3o\%3, Accessed date: 12 October 2019.

Köhler, H.A., 1887. Köhler's Medizinal-Pflanzen in naturgetreuen Abbildungen mit kurz erläuterndem Texte: Atlas zur Pharmacopoea germanica, austriaca, belgica, danica, helvetica, hungarica, rossica, suecica, Neerlandica, British pharmacopoeia, zum Codex medicamentarius, sowie zur Pharmacopoeia of the United States of America. Gera-Untermhaus. Verlag von Fr, Eugen Köhler.

Kolbe, H., 1874. Ueber eine neue Darstellungsmethode und einige bemerkenswerte Eigenschaften der Salicylsäure. J. Prakt. Chem. 10, 89-112.

Leonti, M., Verpoorte, R., 2017. Traditional Mediterranean and european herbal medicines. J. Ethnopharmacol. 199, 161-167.

Leonti, M., Nebel, S., Rivera, D., Heinrich, M., 2006. Wild gathered food plants in the European Mediterranean: a comparative analysis. Econ. Bot. 60, 130-142.

Leonti, M., Cabras, S., Castellanos, M.E., Challenger, A., Gertsch, J., Casu, L., 2013. Bioprospecting: evolutionary implications from a post-olmec pharmacopoeia and the relevance of widespread taxa. J. Ethnopharmacol. 147, 92-107.

Leonti, M., Staub, P.O., Cabras, S., Castellanos, M.E., Casu, L., 2015. From cumulative cultural transmission to evidence-based medicine: evolution of medicinal plant knowledge in Southern Italy. Front. Pharmacol. 6, 207.

Lewin, L., 1894. Die Pfeilgifte: historische und experimentelle Untersuchungen. Reimer, Berlin.

Lewinsohn, T.M., Prado, P.I., 2005. How many species are there in Brazil? Cons. Biol. 19, 619-624.

Lewis, H.M., Laland, K.N., 2012. Transmission fidelity is the key to the build-up of cumulative culture. Philos. Trans. R. Soc. Lond. B Biol. Sci. 367, 2171-2180.

Liebig, J.v., 1837. Anleitung zur Analyse organischer Körper. Verlag Vieweg, Braunschweig.

Liebig, J.v., Geiger, P.L., 1943. Handbuch der Organischen Chemie - mit Rücksicht auf Pharmacie. Verlag Winter, Leipzig und Heidelberg.

Linares, E., Bye, R.A., 1987. A study of four medicinal plant complexes of Mexico and adjacent United States. J. Ethnopharmacol. 19, 153-183.

Logan, M.H., Dixon, A.R., 1994. Agriculture and the acquisition of medicinal plant knowledge. In: Etkin, Nina L. (Ed.), Eating on the Wild Side. University of Arizona Press, Tucson, pp. 25-45.

Lorenzi, H., Matos, F.J.A., 2008. Plantas medicinais no Brasil. Nativas e exóticas, 2. ed. Nova Odessa, Plantarum.

Mann, R.D., 1984. Modern Drug Use: an Enquiry on Historical Principles. MTP Press Limited, Lancaster, UK.

Michaud, D.S., 2002. The epidemiology of pancreatic, gallbladder, and other biliary tract cancers. Gastrointest. Endosc. 56, S195-S200.

Milliken, W., Albert, B., 1996. The use of medicinal plants by the Yanomami Indians of Brazil. Econ. Bot. 50, 10-25.

Monardes, N., 1574. Primera y segunda y tercera parte de la Historia Medicinal de las cosas que se traen de nuestras Indias Occidentales que sirven en Medicina. Sevilla. En casa de Fernando Diaz. Reproducción facsimilar en Monardes (1989).

Monigatti, M., Bussmann, R.W., Weckerle, C.S., 2013. Medicinal plant use in two Andean communities located at different altitudes in the Bolívar Province. Peru. J Ethnopharmacol 145, 450-464.

Munger, R.S., 1949. Guaiacum, the holy wood from the new world. J. Hist. Med. Allied Sci. 4, 196-229.

Niewöhner, J., Lock, M., 2018. Situating Local Biologies: Anthropological Perspectives on Environment/human Entanglements BioSocieties (2018). pp. 1-17.

Odonne, G., Valadeau, C., Alban-Castillo, J., Stien, D., Sauvain, M., Bourdy, G., 2013. Medical ethnobotany of the chayahuita of the paranapura basin (Peruvian Amazon). 
J. Ethnopharmacol. 146, 127-153.

Odonne, G., Houël, E., Bourdy, G., Stien, D., 2017. Treating leishmaniasis in Amazonia: a review of ethnomedicinal concepts and pharmaco-chemical analysis of traditional treatments to inspire modern phytotherapies. J. Ethnopharmacol. 199, 211-230.

Osol, A., Farrar, G.E. (Eds.), 1955. The Dispensatory of the United States of America, 25th Edition. Lippincott Comp., Philadelphia.

Pandalis, G., Keil, G., 2014. Urheimische Medizin". A modern medicine against the background of geographical origin and ethnicity Urheimische Medizin: Moderne Heilkunde vor dem Hintergrund geografischer Herkunft und Ethnie]. Z. Phytother. 35, 71-75.

Paniagua-Zambrana, N., Cámara-Leret, R., Macía, M.J., 2015. Patterns of Medicinal Use of Palms Across Northwestern South America. Bot. Rev. 81, 317-415.

Pedrollo, C.T., Kinupp, V.F., Shepard Jr., G., Heinrich, M., 2016. Medicinal plants at rio Jauaperi, Brazilian Amazon: ethnobotanical survey and environmental conservation. J. Ethnopharmacol. 186, 111-124.

Pereda-Miranda, R., Fragoso-Serrano, M., Escalante-Sánchez, E., Hernández-Carlos, B., Linares, E., Bye, R., 2006. Profiling of the resin glycoside content of Mexican jalap roots with purgative activity. J. Nat. Prod. 69, 1460-1466.

Pianetti, G.A., 2016. Farmacopeia Brasileira - uma Breve História. https://cemefarufmg. tumblr.com/post/142090288939/farmacopeia-brasileira-uma-breve-hist\%C3\% B3ria, Accessed date: 12 April 2019.

Pio Correa, M., 1926-1975. Dicionario Das Plantas Uteis Do Brasil E Das Exoticas Cultivadas Volumes I - VI. Ministerio da Agricultura, Industria e Commercio, Rio de Janeiro.

Pontes, C.E.C., 2017. Patentes de medicamentos e a indústria farmacêutica nacional: estudo dos depósitos feitos no Brasil. Revista Produção e Desenvolvimento 3, 38-51.

Prance, G.T., 1973. An ethnobotanical comparison of four tribes of amazonian Indians. Acta Amazonica 2, 7-27.

Prance, G.T., 2005. The Migrations of plants. In: Prance, G.T., Nesbitt, M. (Eds.), The Cultural History of Plants. Routledge, New York, pp. 27-28.

RENAME, 2015. Relação Nacional de Medicamentos Essenciais [National Relation of Essential Medicines. (RENAME/2015)]

Ribeiro, D., 2018. O Povo Brasileiro: a formação e o sentido do Brasil, 3 ed. Global Editora, São Paulo.

Ribeiro, R.V., Bieski, I.G.C., Balogun, S.O., Martins, D.T.O., 2017. Ethnobotanical study of medicinal plants used by ribeirinhos in the North araguaia microregion, Mato Grosso, Brazil. J. Ethnopharmacol. 205, 69-102.

Ricardo, L.M., Dias, B.M., Mügge, F.L.B., Leite, V.V., Brandão, M.G.L., 2018. Evidence of traditionality of Brazilian medicinal plants: the case studies of Stryphnodendron adstringens (Mart.) Coville (barbatimão) barks and Copaifera spp. (copaíba) oleoresin in wound healing. J. Ethnopharmacol. 219, 319-336.

Richerson, P.J., Christiansen, M.H. (Eds.), 2013. Cultural Evolution: Society, Technology, Language, and Religion. MIT Press, Cambridge.

Rivera, D., Verde, A., Obón, C., Alcaraz, F., Moreno, C., Egea, T., Fajardo, J., Palazón, J.A., Valdés, A., Signorini, M.A., Bruschi, P., 2017. Is there nothing new under the sun? The influence of herbals and pharmacopoeias on ethnobotanical traditions in Albacete (Spain). J. Ethnopharmacol. 195, 96-117.

Rodrigues, E., 2006. Plants and animals utilized as medicines in the Jaú national park (JNP), Brazilian Amazon. Phytother Res. 20, 378-391.

Schultes, R.E., Raffauf, R.F., 1990. The Healing Forest: Medicinal and Toxic Plants of the Northwest Amazonia. Dioscorides Press, Portland.
Shaffer, A.A., 2006. Epidemiology of gallbladder stone disease. Best Pract. Res. Clin. Gastroenterol. 20, 981-996.

Shepherd, G.J., 2003. Terrestrial plants. Pages 53-55. In: Lewinsohn, T.M. (Ed.), organizer. Evaluation of the state of knowledge on biological diversity in Brazil: executive summary. Programa Nacional da Diversidade Biológica, Ministério do Meio Ambiente, Brasília

Stevens, G.C., 1989. The latitudinal gradient in geographical range: how so many species coexist in the tropics. Am. Nat. 133, 240-256.

Stocker, R., 1810. Pharmacopœia Officinalis Britannica, Being a New and Correct Translation of the Late Edition of the London Pharmacopœia, with Which Are Incorporated in Alphabetical Order All the Formulæ of the Edinburgh and Dublin Colleges; Printed for Cox, St. Thomas's-street. Borough, London. https://www. survivalinternational.org/tribes/brazilian, Accessed date: 12 April 2019 survivalinternational.org.

Thomson, A.T., 1826. The London Dispensatory, a Practical Synopsis of Materia Medica, Pharmacy, and Therapeutics, fourth ed. Printed for Longman, Rees, Orme, Brown, and Green; Paternoster-row, London.

Thomson, A.T., 1862. A Conspectus of the Pharmacopoeias of the London, Edinburgh, and Dublin Colleges of Physicians, and of the United States Pharmacopoeia: Being a Practical Compendium of Materia Medica and Pharmacy. W. Wood. Tropicos. http:// www.tropicos.org/Project/VPA, Accessed date: 12 April 2019.

Tschirch, A., 1909-1925. Handbuch der Pharmakognosie. Tauchnitz, Band 1-3. Leipzig.

Tschirch, A., 1910. Handbuch der Pharmakognosie. Allgemeine Pharmakognosie, Erster Band II. Abteilung. Chr. Herm. Tauchnitz, Leipzig.

Tschirch, A., 2015. Handbuch der Pharmakognosie. Allgemeine Pharmakognosie, Erste Abteilung, vol. 1 Chr. Herm. Tauchnitz, Leipzig.

Ulloa Ulloa, C., Acevedo-Rodríguez, P., Beck, S., Belgrano, M.J., Bernal, R., Berry, P.E., Brako, L., Celis, M., Davidse, G., Forzza, R.C., Gradstein, S.R., Hokche, O., León, B., León-Yánez, S., Magill, R.E., Neill, D.A., Nee, M., Raven, P.H., Stimmel, H., Strong, M.T., Villaseñor, J.L., Zarucchi, J.L., Zuloaga, F.O., Jørgensen, P.M., 2017. An integrated assessment of the vascular plant species of the Americas. Science 358, 1614-1617.

Unschuld, P.U., 1986. Medicine in China. A History of Pharmaceutics. Berkley.

Urdang, G., 1951. The development of pharmacopoeias; a review with special reference to the pharmacopoea Internationalis. Bull. World Health Organ. 4, 577-603.

van Andel, T.R., van 't Klooster, C.I., Quiroz, D., Towns, A.M., Ruysschaert, S., van den Berg, M., 2014. Local plant names reveal that enslaved Africans recognized substantial parts of the New World flora. Proc. Natl. Acad. Sci. U.S.A. 111, E5346-E5553.

von Hofmann, A.W., 1843. Chemische Untersuchungen der Basen im Steinkohlen Theeröl. Ann. Chem. Pharm. 47, 37-87.

Wagner, H., Vollmar, A., Bechthold, A., 2007. Pharmazeutische Biologie 2. Wissenschaftliche Verlagsgesellschaft mbH, Stuttgart, Germany.

Waugh, M.A., 1982. Role played by Italy in the history of syphilis. Br. J. Vener. Dis. 58, 92-95.

Wolfe, N.D., Dunavan, C.P., Diamond, J., 2007. Origins of major human infectious diseases. Nature 447, 279-283.

Wood, G.B., Bache, F., 1833. The Dispensatory of the United States.

Zohary, D., Hopf, M., 2000. Domestication of Plants in the Old World: the Origin and Spread of Cultivated Plants in West Asia, Europe and the Nile Valley, third ed. Oxford University Press, Oxford, United Kingdom. 